\title{
A study on knowledge, attitude and practice of biomedical waste management among health care workers in a Tertiary Care Hospital in Puducherry
}

\author{
Monika Sekar ${ }^{1}$, Swapna M.², Joshy M Easow ${ }^{3}$ \\ ${ }^{\mathbf{1}}$ MBBS Student, ${ }^{\mathbf{2}}$ Assistant Professor, ${ }^{3}$ Professor \& HOD, Dept. of Microbiology, ${ }^{\mathbf{1}, 2}$ Sri Venkateshwara Medical College, \\ Hospital and Research Centre, ${ }^{3}$ Mahatama Gandhi Medical College and Research Institute
}

*Corresponding Author:

Email: swapnamuthuswamy@gmail.com

\begin{abstract}
Introduction: Health care workers (HCWs) are constantly associated with generation, segregation and disposal of biomedical wastes (BMW). Knowledge, attitude and practice (KAP) of BMW management among HCWs are the three determinants used to evaluate the effective functioning of BMW management system of the Institution.

Aims: This study aims to detect the degree of knowledge, attitude and practice of BMW management among HCWs in a tertiary care hospital.

Materials and Methods: This study included $150 \mathrm{HCW}$ s from five groups (postgraduates, interns, nurses, technicians and sanitary staffs), each group comprising of 30 individuals. They were instructed to tick their response in the questionnaire containing 30 questions (10 questions about each parameter) and were graded as good, average and poor based on individual score.

Results: Order of decreasing knowledge and practice seen among the five groups was postgraduates followed by laboratory technicians, interns, nurses and sanitary staffs. Decreasing order of attitude was postgraduates, interns and laboratory technicians with same score, followed by nurses and sanitary staffs. In our study, $81.33 \%, 86.7 \%$ and $69.33 \%$ of participants had above average KAP values respectively.

Conclusion: Postgraduates and interns had better understanding of BMW management than other groups. Laboratory technicians were better than nurses and sanitary staffs. Sanitary workers were highly ignorant regarding BMW management. So a continuing medical education program on BMW management should be conducted on yearly basis to train and update newly appointed as well as existing HCWs.
\end{abstract}

Keywords: Attitude, Biomedical waste, Knowledge, Practice, Questionnaire.

\section{Introduction}

Biomedical waste (BMW) includes waste generated during diagnosis, treatment or immunization of human beings or animals or research activities or in production or testing of biologicals. ${ }^{1}$ BMW handling rules have been notified in 1998 and updated in March 2016. Health care setting is a major contributor of biomedical wastes. In India, about 0.33 million tons of hospital waste is generated annually. ${ }^{2}$ BMW management is an integral part of infection control program and if mismanaged, medical wastes can contaminate the entire environment of the hospital. ${ }^{3}$ All individuals exposed to BMW are potentially at risk of being injured or infected if not handled properly and causes environmental degradation if not managed appropriately. ${ }^{4}$ The problem is fueled further by the lack of awareness about health hazards from BMW, financial and manpower constraints. ${ }^{5}$ Health care workers (HCWs) are constantly associated with generation, segregation and disposal of biomedical wastes. Knowledge, attitude and practice (KAP) among HCWs are the three determinants used to assess the effective functioning of BMW management system in the Institution. Knowledge is defined as the awareness regarding biomedical waste management. Attitude is defined as their feelings towards BMW management. Practice is defined as the identification, segregation and packaging of biomedical wastes. ${ }^{6}$ Adequate knowledge about health hazards of BMW, right attitude towards handling of BMW and practice of safety measures can ensure safe disposal of these wastes. In developing countries, biomedical wastes have not received sufficient attention, hence BMW management is still a challenge to the hospitals. ${ }^{7}$

\section{Aims and Objectives}

This study has been carried out to assess the knowledge, attitude and practice of BMW management among HCWs in our tertiary care hospital. This study also compared the KAP values between various groups and detected the degree of correlation between KAP values within each group.

\section{Materials and Methods}

This is a cross sectional study done in our Institution, during 2016 involving 150 health care workers. HCWs relatively free during that session were selected randomly and included in the study. Individuals posted in casualty, operation theatres and individuals not willing to participate were excluded from the study.

Five groups (postgraduates, interns, nurses, laboratory technicians and sanitary staffs) were selected among the health care personnel and 30 in each group were included in the study with their prior consent. Study groups were group I-postgraduates, group II- interns, group III- nurses, group IV- laboratory technicians and group V-sanitary staffs. Necessary permissions were 
obtained from Institutional ethical and research committee before the commencement of study. In our study, three determinants (KAP) were assessed using predesigned questionnaire containing 30 questions, 10 for each determinant. Questions were selected and designed from literatures based on biomedical waste management rules 2015 and 2016. Questionnaire was issued and collected after 30 minutes. For sanitary staffs, the questionnaire was given in native language. Each correct response was given one score and the total was calculated for each determinant. They were graded as good, average and poor based on the scores secured. If the score was 8-10/10, they were graded as good, if 5$7 / 10$, grade was average and $0-4 / 10$ was graded as poor. Data was tabulated and analyzed using SPSS version 23.0 statistical package. Descriptive statistics (percentage, mean and standard deviation) was used to describe the variables and correlation test was used to identify their correlation.

\section{Results}

A total of $150 \mathrm{HCWs}$ were included in this study. Level of knowledge, attitude and practice regarding BMW management among the five groups were in shown in table 1. Mean, standard deviation and correlation coefficient between the three determinants were shown in table 3 .

\section{Discussion}

Biomedical wastes are generated from all levels of health care facilities. Segregation of biomedical waste at the point of generation not only reduces the financial expenditure for management of BMW, but also the health hazards due to handling of these wastes. BMW management system of our Institution has been analyzed using three determinants, KAP. Study participants were from various groups (group I-postgraduates, group IIinterns, group III-nurses, group IV-laboratory technicians and group $\mathrm{V}$-sanitary staffs) belonging to our Institution. The decreasing order of knowledge and practice seen among the five groups was postgraduates followed by laboratory technicians, interns, nurses and sanitary staffs. The decreasing order of attitude was postgraduates followed by interns and laboratory technicians with same score, nurses and sanitary staffs.(Table 1) A similar study by Mathur et al showed that doctors, nurses and laboratory technicians had a better knowledge than sanitary staffs. ${ }^{8}$ The study by Ajai Singh et al showed that nurses had better attitude and practice of BMW management even more than doctors. ${ }^{9}$ Another study by Madhukumar S et al showed that nurses had better attitude than technicians and sanitary staffs. ${ }^{[10]}$ In our study, postgraduates were the toppers in all three determinants and laboratory technicians had better KAP values than nurses contrary to the findings of other studies.

Mean score for knowledge, attitude and practice were $6.04,6.78$ and 6.20 respectively. (Table 2) In the study done by SengodanVC et al involving doctors and nurses, mean score for KAP were 7.74, 7.67 and 6.58 respectively. ${ }^{11}$ Lower KAP values in our study could be due to the inclusion of sanitary staffs, the group which was not included in Sengodan VC et al study. Overall mean values of KAP has been affected by the lower scores of sanitary staffs in our study. Our study showed that sanitary staffs had poor KAP values among all groups of health care workers which is the same as the findings in the study done by Madhukumar $\mathrm{S}$ et al. ${ }^{10}$ Involvement of sanitary staffs conveys more meaning to the study since they play an important role in the disposal of BMW. In our study, $81.33 \%$ of participants had average knowledge, which is better than the study done by Sharma A et al where $62.6 \%$ of participants had satisfactory knowledge. ${ }^{12}$ Arora et al in their study concluded that majority of the respondents have unsatisfactory knowledge, attitude and inadequate practices related to waste management. ${ }^{13}$ Another reason for lower KAP values in our study could be due to the changes in colour coding of bins in the year 2016, that most of the participants were unaware, which emphasizes the need for keeping themselves updated. Only $21 \%$ of our participants have received training on BMW management. The study conducted by Ananthachari KR et al, Srivastav S and Dudi M et al have shown $28 \%, 30 \%$ and $37 \%$ of their participants had attended BMW management training respectively. ${ }^{14-16}$

Correlation between the three determinants was assessed for each group. (Table 3) For postgraduates, interns, nurses, lab technicians and sanitary staffs, correlation between knowledge and attitude was 0.269 , $0.226,0.573,0.050$ and 0.218 and correlation between knowledge and practice was $0.293,0.200,0.312,0.160$ and 0.049 respectively. Though the KAP scores were low for nurses, they had good correlation between the parameters when compared to other groups. Postgraduates and laboratory technicians had better correlation between knowledge and practice compared to knowledge and attitude, but the reverse was true with the other three groups. The study by Wai et al showed that there was a significant association between knowledge and practice with a correlation coefficient of 0.390 and knowledge and attitude with a correlation coefficient of $0.289 .{ }^{17}$ Saini et al in their study observed a significant gap in the KAP regarding BMW disposal among HCWs. ${ }^{18}$

Three noteworthy findings observed in our study were nurses had lower KAP values when compared to laboratory technicians, sanitary staffs were the lowest scorers and attitude of the participants regarding BMW management was good compared to other determinants. Reason for lower KAP values among nurses than laboratory technicians could be explained by the fact that majority of participants in nurses group were newly recruited juniors, as the senior nurses who had busy work schedule were unable to participate in the study. This is supported by the study done by Ajmera V et al, which 
showed newly appointed nurses used colour coded bins inappropriately. ${ }^{19}$ According to the study by Nagaraju B et al, elderly and experienced health care workers had better awareness regarding BMW management compared to the younger and less experienced ones. ${ }^{20}$ Sanitary staffs are the group involved in disposal of BMW and they play a major role in ensuring a safe hospital environment. There are studies on KAP of BMW management which have not included sanitary staffs and studies that included them have shown that they had least knowledge, less favorable attitude and poor practice in BMW management. The study by Anand $\mathrm{P}$ et al also found that sanitary workers had very low KAP values regarding BMW management. ${ }^{21}$ Sanitary staffs remain as the grey area and therefore CMEs and training programs should be specifically addressed to cover this group by means of native language and pictorial representations. HCWs of our Institution has got better attitude towards BMW management when compared to knowledge and practice. This could be due to the reason that questions on knowledge were answered only if theoretical knowledge was sound and questions on attitude were answered easily because options were of affirmative type.

Awareness regarding BMW management can be increased by improving the knowledge which will positively impact the attitude and practice. As per the study done by Saini et al, people with higher education and knowledge had better attitudes towards the subject. ${ }^{18}$ Awareness can be improved by organizing continuous medical education (CME) program on a yearly basis.

Table 1: Percentage of KAP of BMW management among different groups

\begin{tabular}{|c|c|c|c|c|c|c|c|c|c|}
\hline \multirow{2}{*}{$\begin{array}{c}\text { HCW } \\
\text { group }\end{array}$} & Good & Average & Poor & Good & Average & Poor & Good & Average & Poor \\
\hline Group I & 46.6 & 53.3 & 0 & 70 & 26.6 & 3.3 & 53.3 & 33.3 & 13.3 \\
\hline Group II & 20 & 70 & 10 & 50 & 46.6 & 3.3 & 20 & 60 & 20 \\
\hline Group III & 13.3 & 70 & $\begin{array}{c}16.6 \\
7\end{array}$ & 30 & 40 & 30 & 16.6 & 40 & 43.3 \\
\hline Group IV & 16.67 & 76.67 & 6 & 43.3 & 53.33 & 3.3 & 16.6 & 73.3 & 10 \\
\hline Group V & 0 & 40 & 60 & 6.67 & 66.67 & 20 & 6 & 33.3 & 66.6 \\
\hline
\end{tabular}

Table 2: Mean and standard deviation of KAP among different groups

\begin{tabular}{|l|c|c|c|c|c|c|}
\hline \multirow{2}{*}{ HCW group } & \multicolumn{6}{|c|}{ Score } \\
\cline { 2 - 7 } & \multicolumn{2}{|c|}{ Knowledge } & \multicolumn{2}{c|}{ Attitude } & \multicolumn{2}{c|}{ Practice } \\
\cline { 2 - 7 } & Mean & SD & Mean & SD & Mean & SD \\
\hline Group I & 7.47 & 1.96 & 7.83 & 1.96 & 7.07 & 1.87 \\
\hline Group II & 6.47 & 1.33 & 7.37 & 1.47 & 7.37 & 1.57 \\
\hline Group III & 5.67 & 1.83 & 6.00 & 1.91 & 6.00 & 2.21 \\
\hline Group IV & 6.47 & 1.36 & 7.17 & 1.34 & 6.50 & 1.43 \\
\hline Group V & 4.10 & 1.47 & 5.53 & 1.22 & 4.03 & 1.40 \\
\hline Total & 6.04 & 1.59 & 6.78 & 1.58 & 6.20 & 1.70 \\
\hline
\end{tabular}

Table 3: Correlation coefficient of BMW management among different groups

\begin{tabular}{|c|c|c|}
\hline \multirow{2}{*}{ HCW group } & \multicolumn{2}{|c|}{ Correlation coefficient } \\
\cline { 2 - 3 } & Knowledge and attitude & Knowledge and practice \\
\hline Group I & 0.269 & 0.293 \\
\hline Group II & 0.226 & 0.200 \\
\hline Group III & 0.573 & 0.312 \\
\hline Group IV & 0.050 & 0.160 \\
\hline Group V & 0.218 & 0.049 \\
\hline
\end{tabular}

\section{Conclusion}

In our study postgraduates and interns had better understanding of BMW management than other groups. Laboratory technicians were better than nurses and sanitary staffs. Sanitary workers were highly ignorant regarding BMW management. So a continuing medical education program on BMW is mandatory atleast once in a year to train new batches of postgraduates, interns, newly appointed health care workers and serves as an update for the existing health care workers.
Financial support: We thank the Indian Council of Medical Research, New Delhi, India for providing Short term research studentship to the first author (STS Ref ID:2016-04717).

Conflicts of interest: There are no conflicts of interest 


\section{References}

1. National guidelines on hospital waste management based up on the bio-medical waste management and handling rules, 1998. Government of India, Ministry of Health and Family Welfare. New Delhi

2. Patil AD, Shekdar AV. Health care waste management in India. J Environ Manage 2001;63:211-20.

3. Babu BR, Parande AK, Rajalaksmi R, Suriyakala P, Volga M. Management of biomedical waste in India and other countries. A review. J Int Environ Appl Sci 2009;4:65-78.

4. Radha R. Assessment of existing KAP regarding biomedical waste management among health care workers in tertiary care rural hospital. Int J Health Sci Res 2012;2:14-9.

5. Pandit NB, Mehta HK, Kartha GP, Choudhary SK. Management of biomedical waste management: awareness and practice in a district of Gujarat. Indian J Public Health 2005;49:245-7.

6. Park K. Hospital waste management. In Park's textbook of preventive and social medicine. $22^{\text {nd }}$ ed. Jabalpur: M/S Banarasidas Bhanot publishers;2009.p.694-9.

7. Silva CE, Hoppe AE. Ravanello MM, Mello N. Medical waste management in the south of Brazil. Waste Manag 2005;25:600-5.

8. Mathur V, Dwivedi S, Hassan MA, Misra RP. Knowledge, attitude and practices about bio-medical waste management among health care personnel: a crosssectional study. Indian J Community Med 2011;36:143-5.

9. Ajai S, Nath RS. Knowledge, attitude and practice of biomedical waste management amongst staff of Institutional trauma center level II. Int J Res Health Sci 2013;1:62-8.

10. Madhukumar S, Ramesh G. Study about awareness and practice about health care waste management among hospital staffs in a Medical College Hospital, Banglore. Int J Basic Med Sci 2012;3:8-9.

11. Sengodan VC, Amruth KH. Knowledge, attitude and practice study on biomedical waste management among health care professionals and paramedical students in a tertiary care government hospital in South India. Int J Environ Health Eng 2014;3:11.

12. Sharma A, Sharma S, Sharma S, Singh P. Awareness of Biomedical waste management among health care personeel in Jaipur, Rajasthan Oral Health Dent Manag 2013;12:32-40.

13. Arora L, Agarwal S. Knowledge, attitude and practice regarding waste management in selected hospital students of university of Rajasthan, Jaipur. Int J Chem Environ Pharm Res 2011; 2:40-3.

14. Ananthachari KR, Divya CV. A study on assessment of knowledge on biomedical waste management among health care workers of tertiary care hospital. Int J Community Med Public Health 2016;3:2409-13.

15. Srivastav S, Kariwal P, Singh AK, Shrotriya VP. Evaluation of biomedical waste management practices in multi-speciality tertiary hospital. Indian J Community Health 2009;21:46-50.

16. Dudi M, Sharma R, Sharma S, Jain M. Assessment of the knowledge, attitude and practices regarding biomedical waste management amongst paramedical staff in a tertiary level health care facility. Int J Med Sci Public Health 2016;5:615-9.

17. Wai S, Tantrakarnapa K, Huangprasert S. Knowledge, attitude and practice of Myanmar migrant in Maesot District towards the environmental sanitation conditions. Thai Environ Eng J 2005;19-19.

18. Saini S, Nagarajan SS, Sarma RK. Knowledge, attitude and practice of bio-medical waste management amongst staff of a tertiary level hospital in India. J Acad Hosp Adm 2005;17:1-12.

19. Ajmera V, Jayalakshmi LS. A study to assess the knowledge regarding biomedical waste management among B.sc nursing students of selected nursing colleges of Udaipur (Raj). International Journal of Science and Research 2016;5:1734-8.

20. Nagaraju B, Padmavathi GV, Puranik DS, Shantharaj MP, Sampulatha SP. A study to assess the knowledge and practice on biomedical waste management among the health care providers working in PHCs of Bagepalli Taluk with the view to prepare informational booklet. Int J Med Biomed Res 2013;2:28-35.

21. Anand P, Jain R, Dhyani A. Knowledge, attitude and practice of biomedical waste management among health care personnel in a teaching Institution in Haryana, India. Int J Res Med Sci 2016;4:4246-50.

How to cite this article: Sekar M, Swapna M, Easow JE. A study on knowledge, attitude and practice of biomedical waste management among health care workers in a Tertiary Care Hospital in Puducherry. Indian J Microbiol Res 2018;5(1):57-60. 